\title{
Role of inherited thrombophilic profile on survival of patients with sepsis
}

\author{
Alexandra Georgakopoulou, ${ }^{1}$ Matthaios Papadimitriou-Olivgeris, ${ }^{2}$ \\ Marina Karakantza, ${ }^{1}$ Markos Marangos (1) 1
}

'Division of Hematology, Department of Internal Medicine, Medical School, University of Patras, Patras, Greece

${ }^{2}$ Division of Infectious Diseases, Department of Internal Medicine, Medical School, University of Patras, Patras, Greece

\section{Correspondence to} Professor Markos Marangos; mmarangos@yahoo.com

Received 19 February 2019 Revised 7 June 2019 Accepted 15 June 2019 Published Online First 11 July 2019
Check for updates

(C) American Federation for Medical Research 2019. No commercial re-use. See rights and permissions. Published by BMJ.

To cite: Georgakopoulou A, Papadimitriou-Olivgeris $\mathrm{M}$, Karakantza M,

\section{ABSTRACT}

The existence of various coagulation and/or fibrinolytic system disorders (such as inherited thrombophilia) in patients with sepsis could possibly modify host response to infection as well as patient outcome. The aim of the study is to investigate inherited thrombophilic profile in patients with sepsis. Eighty-three patients with sepsis admitted at the Department of Internal Medicine of the University General Hospital of Patras, Greece were included. Thrombophilic profile (factor V G1691A (Leiden), factor V H1299R (R2), prothrombin G20210A, MTHFR C677T, MTHFR A1298C, factor XIII V34L, $\beta$-fibrinogen-455 G-A and plasminogen activator inhibitor (PAI)-1 4G/5G) was evaluated using the cardiovascular diseases (CVD) StripAssay based on DNA isolation, PCR and reverse hybridisation. Data were collected from patients' chart reviews. Seventy patients (84.3\%) of the 83 enrolled had at least one thrombophilic mutation. The most common mutations were heterozygous for $\beta$-fibrinogen-455 G-A (43.4\%), heterozygous for factor XIII V34L (32.5\%), PAI-1 4G/4G (26.5\%), homozygous MTHFR C677T (22.9\%), heterozygous factor V H1299R (R2) (13.3\%) and homozygous MTHFR A1298C (12.0\%). A 30-day mortality was $14.5 \%$. Multivariate analysis revealed that mortality was independently associated with Simplified Acute Physiology Score II score on admission, pneumonia and fibrinogen on admission. Nine patients (10.8\%) developed septic shock. Coagulation disorders on admission, bacteraemia and PAI-1 genotype 5G/5G were independently associated with development of septic shock. The presence of thrombophilic mutations in patients with sepsis may affect their clinical response, and future studies are needed in order to elucidate the role of isolated thrombophilic mutations in patients with sepsis or septic shock.

\section{INTRODUCTION}

Sepsis remains a major public health issue, which is characterised by a dysregulated host response to infection and leads to increased morbidity and mortality. ${ }^{12}$ It is well known that sepsis is a life-threatening organ dysfunction caused by a dysregulated host response to infection. ${ }^{1}$ Particularly in sepsis, the coagulation cascade is activated, while the anticoagulant mechanisms and fibrinolysis are downregulated. ${ }^{3-6}$ In turn, the dysregulation of coagulation system and

\section{Significance of this study}

What is already known about this subject?

- Coagulation disorders are important causes of sepsis morbidity and mortality.

- Haemostatic gene polymorphisms' role on sepsis morbidity have been studied with conflicting results.

- 4G/4G genotype of plasminogen activator inhibitor 1 was associated with increased risk for complications during meningococcal disease.

What are the new findings?

- Low fibrinogen levels were independently associated with mortality.

- Mortality was not influenced by thrombophilic profile.

- $5 \mathrm{G} / 5 \mathrm{G}$ genotype of the plasminogen activator inhibitor 1 was independently associated with development of septic shock.

How might these results change the focus of research or clinical practice?

- Studies with large number of participants are needed in order to clarify the impact of haemostatic gene polymorphisms and especially plasminogen activator inhibitor 1 on septic shock development and mortality among patients with sepsis.

subsequent thrombin deposition represent a crucial part of the host response to infection that considerably affects severity and clinical course of sepsis. ${ }^{36-9}$ The clinical expression of such dysregulation is deep vein thrombosis and pulmonary embolism ${ }^{10}$; therefore, it is strongly recommended to use unfractionated heparin or low-molecular-weight heparin in order to prevent aforementioned complications. ${ }^{11}$

The role of haemostatic gene polymorphisms in sepsis-induced coagulopathy disorders and subsequently to mortality has been studied especially in animal models, with sometimes conflicting results. ${ }^{8}{ }^{12}$ The most commonly recognised mutation in haemostatic gene is the factor V Leiden (fVL) mutation and it is thoroughly studied in meningococcal disease. In a previous study, patients with heterozygous fVL 
Table 1 Univariate analysis of predictors of 30-day mortality of patients admitted to the Department of Internal Medicine with sepsis

\begin{tabular}{|c|c|c|c|}
\hline Characteristics & $\begin{array}{l}\text { Survivors } \\
\text { (71 patients) }\end{array}$ & $\begin{array}{l}\text { Non survivors } \\
\text { (12 patients) }\end{array}$ & $P$ value \\
\hline \multicolumn{4}{|l|}{ Demographics } \\
\hline Gender (male) & $38(53.5 \%)$ & $3(25.0 \%)$ & 0.116 \\
\hline Age (years) & $65.4 \pm 20.2$ & $78.5 \pm 14.4$ & 0.011 \\
\hline \multicolumn{4}{|l|}{ Comorbidities } \\
\hline Charlson Comorbidity Index & $3.0 \pm 2.0$ & $5.3 \pm 2.6$ & 0.003 \\
\hline COPD & $8(11.3 \%)$ & $3(25.0 \%)$ & 0.194 \\
\hline Cerebrovascular accident & $8(11.3 \%)$ & $2(16.7 \%)$ & 0.633 \\
\hline Diabetes mellitus & $15(21.1 \%)$ & $0(0.0 \%)$ & 0.112 \\
\hline $\begin{array}{l}\text { Malignancy (haematological } \\
\text { or solid organ) }\end{array}$ & $5(7.0 \%)$ & $2(16.7 \%)$ & 0.266 \\
\hline \multicolumn{4}{|l|}{ Admission data } \\
\hline $\begin{array}{l}\text { Duration of symptoms before } \\
\text { admission (days) }\end{array}$ & $2.9 \pm 3.0$ & $1.8 \pm 1.8$ & 0.100 \\
\hline Leucocytes $\left(10^{9} / \mathrm{L}\right)$ & $16.5 \pm 5.9$ & $12.3 \pm 4.4$ & 0.025 \\
\hline $\begin{array}{l}\mathrm{C} \text { reactive protein }(\mathrm{mg} / \mathrm{dL}) \text { on } \\
\text { admission }\end{array}$ & $14.3 \pm 8.6$ & $16.2 \pm 8.7$ & 0.472 \\
\hline Temperature $\left({ }^{\circ} \mathrm{C}\right)$ & $38.7 \pm 0.6$ & $37.8 \pm 1.5$ & 0.035 \\
\hline SAPS II Score on admission & $36.9 \pm 13.4$ & $61.1 \pm 15.0$ & $<0.001$ \\
\hline SOFA Score on admission & $4.3 \pm 2.2$ & $7.1 \pm 1.9$ & $<0.001$ \\
\hline Acute kidney injury & $11(15.5 \%)$ & $7(58.3 \%)$ & 0.003 \\
\hline LOS (days) & $11.0 \pm 9.1$ & $12.6 \pm 14.2$ & 0.984 \\
\hline \multicolumn{4}{|l|}{ Infection severity } \\
\hline Sepsis & $66(93.0 \%)$ & $8(66.7 \%)$ & \\
\hline Septic shock & $5(7.0 \%)$ & $4(25.0 \%)$ & $0.022^{*}$ \\
\hline \multicolumn{4}{|l|}{ Type of infection } \\
\hline Pneumonia & $19(26.8 \%)$ & $7(58.3 \%)$ & $0.043^{\dagger}$ \\
\hline Urinary tract infection & $32(45.1 \%)$ & $4(33.3 \%)$ & \\
\hline Abdominal infection & $13(18.3 \%)$ & $0(0.0 \%)$ & \\
\hline Other $^{\ddagger}$ & $7(9.8 \%)$ & $1(8.3 \%)$ & \\
\hline Bacteraemia & $12(16.9 \%)$ & $3(25.0 \%)$ & 0.447 \\
\hline Microbiological confirmed & $28(39.4 \%)$ & $6(50.0 \%)$ & 1.000 \\
\hline Gram-positive & $4(5.6 \%)$ & $1(8.3 \%)$ & \\
\hline Gram-negative & $24(33.8 \%)$ & $5(41.7 \%)$ & \\
\hline \multicolumn{4}{|l|}{ Coagulation data } \\
\hline $\begin{array}{l}\text { Coagulation disorders on } \\
\text { admission }\end{array}$ & $7(9.9 \%)$ & $3(25.0 \%)$ & 0.154 \\
\hline INR & $1.2 \pm 0.2$ & $1.3 \pm 0.2$ & 0.027 \\
\hline PTT (s) & $34.6 \pm 7.9$ & $37.7 \pm 10.5$ & 0.375 \\
\hline Platelets $\left(10^{9} / \mathrm{L}\right)$ & $246.1 \pm 117.2$ & $228.5 \pm 75.9$ & 0.746 \\
\hline Fibrinogen (g/L) & $650.6 \pm 176.9$ & $518.1 \pm 210.1$ & 0.079 \\
\hline D-dimers (ng/mL) & $2757.6 \pm 2664.5$ & $3731.0 \pm 3139.3$ & 0.392 \\
\hline $\begin{array}{l}\text { Coagulation disorders during } \\
\text { 3rd day of hospitalisation }\end{array}$ & $4(5.6 \%)$ & $4(33.3 \%)$ & 0.013 \\
\hline INR & $1.1 \pm 0.1$ & $1.3 \pm 0.2$ & 0.001 \\
\hline PTT (s) & $37.2 \pm 6.3$ & $37.8 \pm 8.8$ & 0.736 \\
\hline Platelets $\left(10^{9} / \mathrm{L}\right)$ & $235.8 \pm 106.4$ & $174.8 \pm 74.7$ & 0.078 \\
\hline Fibrinogen ( $g / \mathrm{L}$ ) & $668.7 \pm 169.8$ & $533.5 \pm 183.3$ & 0.042 \\
\hline D-dimers (ng/mL) & $2564.3 \pm 1954.1$ & $5748.0 \pm 3593.9$ & 0.012 \\
\hline $\begin{array}{l}\text { Coagulation disorders } \\
\text { during seventh day of } \\
\text { hospitalisation }^{\S}\end{array}$ & $2(2.8 \%)$ & $3(25.0 \%)$ & 0.020 \\
\hline INR & $1.1 \pm 0.1$ & $1.3 \pm 0.3$ & 0.012 \\
\hline PTT (s) & $34.7 \pm 5.7$ & $40.6 \pm 13.7$ & 0.349 \\
\hline
\end{tabular}

Table 1 Continued

\begin{tabular}{clll}
\hline & $\begin{array}{l}\text { Survivors } \\
\text { Characteristics }\end{array}$ & $\begin{array}{l}\text { Non survivors } \\
\text { (71 patients) }\end{array}$ & $\begin{array}{l}\text { (12 patients) } \\
\text { P value }\end{array}$ \\
\hline Platelets $\left(10^{9} / \mathrm{L}\right)$ & $314.5 \pm 126.0$ & $173.1 \pm 52.1$ & 0.001 \\
\hline Fibrinogen $(\mathrm{g} / \mathrm{L})$ & $607.4 \pm 170.4$ & $432.9 \pm 202.2$ & 0.017 \\
\hline D-dimers $(\mathrm{ng} / \mathrm{mL})$ & $2927.5 \pm 1992.1$ & $5814.4 \pm 3772.6$ & 0.049 \\
\hline
\end{tabular}

*Comparison between patients with septic shock against those with sepsis. tComparison between patients with pneumonia against all other causes. ¥Skin and soft-tissue infections and endocarditis.

$\S$ Comparison among 56 patients.

COPD, chronic obstructive pulmonary disease; INR, international normalized ratio; LOS, length of stay; PTT, partial thromboplatin time; SAPS II, Simplified Acute Physiology Score II; SOFA, sequential organ failure assessment.

mutation had increased risk for complications of purpura fulminans during meningococcal disease, while no association with mortality was found. ${ }^{13}$ Another gene polymorphism associated with increased risk for complications of purpura fulminans during meningococcal disease and also mortality is the $4 \mathrm{G} / 4 \mathrm{G}$ genotype of the plasminogen activator inhibitor (PAI)-1. ${ }^{14}$

Existence of inherited thrombophilia in patients with sepsis could possibly affect coagulation system, host response to infection and subsequently clinical course of sepsis. Data on the role of haemostatic gene polymorphisms among patients with sepsis are scarce. The aim of the present study is to investigate the role of such polymorphisms on mortality and development of septic shock.

\section{MATERIALS AND METHODS \\ Study population}

The present study is a prospective one and was performed at the Department of Internal Medicine of the University General Hospital, Patras during a 12-month period. Inclusion criteria were age $\geq 18$ years and admission at the Department of Internal Medicine with sepsis. Exclusion criteria were hospitalisation for less than 24 hours, HIV infection, neutropaenia, moderate to severe cirrhosis, as well as patients receiving immunosuppressive agents or anticoagulant therapy.

Patients were enrolled in the study, within 24 hours of admission. Primary outcome was a 30-day mortality. A secondary analysis was performed in order to assess the role of thrombophilic mutation in the development of septic shock. Data (epidemiological data, comorbidities, severity on admission, laboratory and radiological results) were obtained by patients' chart reviews. Type of infection was defined according to Centers for Disease Control and Prevention (CDC) definition. ${ }^{2}$ According to the Society of Critical Care Medicine (SCCM)/ European Society of Intensive Care Medicine (ESICM)/ American College of Chest Physicians (ACCP)/ American Thoracic Society (ATS)/ Surgical Infection Society (SIS) consensus conference, sepsis was defined as infection with systemic inflammatory response syndrome, and septic shock as sepsis with arterial hypotension despite adequate fluid resuscitation. ${ }^{15}$

\section{Genotypic analysis}

Blood samples in ethylenediaminetetraacetic acid (EDTA)containing tubes for DNA studies were collected on 
Table 2 Thrombophilic profile of patients admitted to the department of internal medicine with sepsis according to mortality or severity of infection

\begin{tabular}{|c|c|c|c|c|c|c|}
\hline Characteristics & $\begin{array}{l}\text { Survivors } \\
\text { (71 patients) }\end{array}$ & $\begin{array}{l}\text { Non survivors } \\
\text { (12 patients) }\end{array}$ & $P$ value & $\begin{array}{l}\text { Sepsis } \\
\text { (74 patients) }\end{array}$ & $\begin{array}{l}\text { Septic shock } \\
\text { (9 patients) }\end{array}$ & $P$ value \\
\hline \multicolumn{7}{|l|}{ FV Leiden } \\
\hline Heterozygote & $4(5.6 \%)$ & $0(0.0 \%)$ & & $4(5.4 \%)$ & $0(0.0 \%)$ & \\
\hline Homozygote & $0(0.0 \%)$ & $0(0.0 \%)$ & $1.000^{*}$ & $0(0.0 \%)$ & $0(0.0 \%)$ & $1.000^{*}$ \\
\hline \multicolumn{7}{|l|}{ FV H1299R (R2) } \\
\hline Heterozygote & $9(12.7 \%)$ & $2(16.7 \%)$ & & $8(10.8 \%)$ & $3(33.3 \%)$ & \\
\hline Homozygote & $1(1.4 \%)$ & $2(16.7 \%)$ & $0.053^{*}$ & $3(4.1 \%)$ & $0(0.0 \%)$ & $1.000^{*}$ \\
\hline \multicolumn{7}{|c|}{ Fll-prothrombin (G20210A) } \\
\hline Heterozygote & $3(4.2 \%)$ & $0(0.0 \%)$ & & $3(4.1 \%)$ & $0(0.0 \%)$ & \\
\hline Homozygote & $0(0.0 \%)$ & $0(0.0 \%)$ & $1.000^{*}$ & $0(0.0 \%)$ & $0(0.0 \%)$ & $1.000^{*}$ \\
\hline \multicolumn{7}{|l|}{ FXIII (V34L) } \\
\hline Heterozygote & $25(35.2 \%)$ & $2(16.7 \%)$ & & $25(33.8 \%)$ & $2(22.2 \%)$ & \\
\hline Homozygote & $1(1.4 \%)$ & $0(0.0 \%)$ & $1.000^{*}$ & $1(1.4 \%)$ & $0(0.0 \%)$ & $1.000^{*}$ \\
\hline \multicolumn{7}{|l|}{$\beta$-fibrinogen } \\
\hline Heterozygote & $29(40.8 \%)$ & $7(58.3 \%)$ & & $32(43.2 \%)$ & $4(44.4 \%)$ & \\
\hline Homozygote & $6(8.5 \%)$ & $0(0.0 \%)$ & $0.356^{*}$ & $5(6.8 \%)$ & $1(11.1 \%)$ & $0.509^{*}$ \\
\hline \multicolumn{7}{|l|}{ MTHFR (C677T) } \\
\hline Heterozygote & $28(39.4 \%)$ & $4(33.3 \%)$ & & $28(37.8 \%)$ & $4(44.4 \%)$ & \\
\hline Homozygote & $14(19.7 \%)$ & $5(41.7 \%)$ & $0.134^{*}$ & $18(24.3 \%)$ & $1(11.1 \%)$ & $0.677^{*}$ \\
\hline \multicolumn{7}{|l|}{ MTHFR (A1298C) } \\
\hline Heterozygote & $28(39.4 \%)$ & $4(33.3 \%)$ & & $27(36.5 \%)$ & $5(55.6 \%)$ & \\
\hline Homozygote & $10(14.1 \%)$ & $0(0.0 \%)$ & $0.344^{*}$ & $9(12.2 \%)$ & $1(11.1 \%)$ & $1.000^{*}$ \\
\hline \multicolumn{7}{|l|}{ PAI-1 genotype } \\
\hline $4 \mathrm{G} / 4 \mathrm{G}$ & $18(25.4 \%)$ & $4(33.3 \%)$ & $0.724 t$ & $22(29.7 \%)$ & $0(0.0 \%)$ & $0.104^{\dagger}$ \\
\hline $4 \mathrm{G} / 5 \mathrm{G}$ & $31(43.7 \%)$ & $3(25.0 \%)$ & $0.343 t$ & $32(43.2 \%)$ & $2(22.2 \%)$ & $0.297^{\dagger}$ \\
\hline $5 G / 5 G$ & $22(31.0 \%)$ & $5(41.7 \%)$ & $0.514 t$ & $20(27.0 \%)$ & $7(77.8 \%)$ & $0.005^{\dagger}$ \\
\hline No of mutations ${ }^{\ddagger}$ & $1.7 \pm 1.1$ & $1.8 \pm 1.2$ & 0.679 & $1.7 \pm 1.1$ & $1.5 \pm 1.2$ & 0.571 \\
\hline
\end{tabular}

${ }^{*}$ Comparison among homozygote against heterozygote or no mutation.

tComparison among each genotype against both other genotypes.

¥Mutation defined as FV G1691A (Leiden) homozygous or heterozygous, FV H1299R (R2) homozygous or heterozygous, FII-prothrombin (G20210A) homozygous or heterozygous, FXIII V34L homozygous or heterozygous, $\beta$-fibrinogen homozygous or heterozygous, PAI-1genotype 4G/4G, MTHFR C677T homozygous, MTHFR A1298C homozygous; presence of homozygous mutation was calculated as one mutation, as was heterozygous.

FV, factor V; PAl-1, plasminogen activator inhibitor-1.

enrolment. The following thrombophilic mutations were evaluated using the cardiovascular diseases (CVD) StripAssay T 4-360 (ViennaLab Labordiagnostika): factor V G1691A, factor V H1299R (R2), prothrombin G20210A, MTHFR C677T, MTHFR A1298C, factor XIII V34L, $\beta$-fibrinogen-455 G-A and PAI-1 4G/4G. The procedure was based on DNA isolation, PCR and reverse hybridization.

\section{Statistical analysis}

Statistical analysis was performed using SPSS V.23.0 (SPSS). The Fisher's exact test or $\mathrm{X}^{2}$ test was employed for categorical variables, while, Mann-Whitney $U$ test or t-test for continuous ones, as appropriate. Multiple logistic regression analysis was used to calculate unadjusted ORs and 95\% CIs. Factors contributing to multicollinearity were excluded from the multivariate analysis. Statistical significance was established at $\mathrm{p}<0.05$.

\section{RESULTS}

Overall 83 patients were enrolled in our study. The most common types of infections were urinary tract infection (36 patients, 43.4\%), pneumonia (26 patients, 31.3\%) and abdominal infections (13 patients, 15.7\%), while the remaining eight infections were skin and soft-tissue infections and endocarditis. Fifteen patients (18.1\%) developed bacteraemia. Only 34 infections (41.0\%) had microbiological confirmation of the pathogen; 29 were caused by gramnegative bacteria and 5 were gram-positive.

Seventy patients $(84.3 \%)$ had at least one thrombophilic mutation. Three patients (3.6\%) had four mutations, 19 (22.9\%) had three mutations and 25 (30.1\%) had two. The most common mutations were heterozygous for $\beta$-fibrinogen-455 G-A $(36 ; 43.4 \%)$, heterozygous for factor XIII V34L (27; 32.5\%), PAI-1 4G/4G (22; 26.5\%), homozygous MTHFR C677T (19; 22.9\%), heterozygous factor V H1299R (R2) (11; 13.3\%) and homozygous MTHFR A1298C (10; 12.0\%).

A 30 -day mortality was $14.5 \%$ (12 patients). Univariate analysis of risk factors for mortality is depicted in tables 1 and 2. No significant differences were found in a 30-day mortality among patients with and without thrombophilic mutations. Multivariate analysis revealed that Simplified Acute Physiology Score II on admission ( $\mathrm{p}=0.014$; OR 1.2, $95 \%$ CI 1.0 to 1.4 ), pneumonia ( $\mathrm{p}=0.016$; OR $33.5,95 \% \mathrm{CI}$ 


\begin{tabular}{|c|c|c|c|}
\hline Characteristics & $\begin{array}{l}\text { Sepsis } \\
\text { (74 patients) }\end{array}$ & $\begin{array}{l}\text { Septic shock } \\
\text { (9 patients) }\end{array}$ & $P$ value \\
\hline \multicolumn{4}{|l|}{ Demographics } \\
\hline Gender (male) & $38(51.4 \%)$ & $3(33.3 \%)$ & 0.483 \\
\hline Age (years) & $65.7 \pm 20.0$ & $79.8 \pm 15.4$ & 0.016 \\
\hline \multicolumn{4}{|l|}{ Comorbidities } \\
\hline Charlson Comorbidity Index & $3.1 \pm 2.1$ & $5.0 \pm 2.4$ & 0.016 \\
\hline COPD & $10(13.5 \%)$ & $1(11.1 \%)$ & 1.000 \\
\hline Cerebrovascular accident & $8(10.8 \%)$ & $2(22.2 \%)$ & 0.296 \\
\hline Diabetes mellitus & $13(17.6 \%)$ & $2(22.2 \%)$ & 0.663 \\
\hline $\begin{array}{l}\text { Malignancy (haematological } \\
\text { or solid organ) }\end{array}$ & $6(8.1 \%)$ & $1(11.1 \%)$ & 0.567 \\
\hline \multicolumn{4}{|l|}{ Admission data } \\
\hline $\begin{array}{l}\text { Duration of symptoms } \\
\text { before admission (days) }\end{array}$ & $2.8 \pm 2.9$ & $2.0 \pm 2.1$ & 0.224 \\
\hline Leucocytes $\left(10^{9} / \mathrm{L}\right)$ & $16.3 \pm 5.7$ & $12.7 \pm 6.5$ & 0.128 \\
\hline $\begin{array}{l}\text { C reactive protein }(\mathrm{mg} / \mathrm{dL}) \\
\text { on admission }\end{array}$ & $14.9 \pm 8.7$ & $12.9 \pm 8.4$ & 0.662 \\
\hline Temperature $\left({ }^{\circ} \mathrm{C}\right)$ & $38.7 \pm 0.7$ & $37.9 \pm 1.3$ & 0.093 \\
\hline SAPS II Score on admission & $37.9 \pm 14.5$ & $61.1 \pm 13.5$ & $<0.001$ \\
\hline SOFA Score on admission & $4.0 \pm 1.9$ & $8.4 \pm 2.2$ & $<0.001$ \\
\hline Acute kidney injury & $11(14.9 \%)$ & $8(88.9 \%)$ & $<0.001$ \\
\hline LOS (days) & $10.9 \pm 9.0$ & $13.2 \pm 16.4$ & 0.866 \\
\hline \multicolumn{4}{|l|}{ Type of infection } \\
\hline Pneumonia & $23(31.1 \%)$ & $3(33.3 \%)$ & $1.000^{\dagger}$ \\
\hline Urinary tract infection & $31(41.9 \%)$ & $5(55.6 \%)$ & \\
\hline Abdominal infection & $13(17.6 \%)$ & $0(0.0 \%)$ & \\
\hline Other $^{\ddagger}$ & $7(9.5 \%)$ & $1(11.1 \%)$ & \\
\hline Bacteraemia & $11(14.9 \%)$ & $4(44.4 \%)$ & 0.052 \\
\hline Microbiological confirmed & $30(40.5 \%)$ & $4(44.4 \%)$ & 1.000 \\
\hline Gram-positive & $3(4.1 \%)$ & $2(22.2 \%)$ & \\
\hline Gram-negative & $27(36.5 \%)$ & $2(22.2 \%)$ & \\
\hline $\begin{array}{l}\text { Coagulation disorders on } \\
\text { admission }\end{array}$ & $6(8.1 \%)$ & $4(44.4 \%)$ & 0.010 \\
\hline INR & $1.2 \pm 0.2$ & $1.3 \pm 0.3$ & 0.115 \\
\hline PTT (s) & $34.4 \pm 7.9$ & $40.3 \pm 10.0$ & 0.079 \\
\hline Platelets $\left(10^{9} / \mathrm{L}\right)$ & $250.0 \pm 110.6$ & $191.0 \pm 116.2$ & 0.110 \\
\hline Fibrinogen $(g / L)$ & $650.1 \pm 183.7$ & $489.5 \pm 139.5$ & 0.297 \\
\hline D-dimers (ng/mL) & $2781.6 \pm 2684.1$ & $3767.5 \pm 3131.7$ & 0.392 \\
\hline
\end{tabular}

*Factors were not included in the multivariate analysis.

†Comparison between patients with pneumonia against all other causes. $\ddagger S k i n$ and soft-tissue infections and endocarditis.

SAPS II, Simplified Acute Physiology Score II.

1.9 to 580.6$)$ and fibrinogen $(\mathrm{p}=0.032$; OR $0.988,95 \% \mathrm{CI}$ 0.977 to 0.999 ) were associated with a 30 -day mortality.

Nine patients (10.8\%) developed septic shock necessitating admission at the intensive care unit. Univariate analysis of risk factors for development of septic shock is depicted in tables 2 and 3. Coagulation disorders on admission ( $\mathrm{p}=0.015$; OR $10.4,95 \%$ CI 1.6 to 68.4 ), bacteraemia $(\mathrm{p}=0.026$; OR $15.3,95 \% \mathrm{CI} 1.7$ to 136.1$)$ and PAI-1 genotype $5 \mathrm{G} / 5 \mathrm{G}$ ( $\mathrm{p}=0.019$; OR $15.1,95 \% \mathrm{CI} 1.6$ to 145.4 ) were independently associated with the development of septic shock.

\section{DISCUSSION}

The majority of patients with sepsis have relevant coagulation abnormalities, ranging from mild decrease in platelet count or weak prolongation of clotting times, to more severe coagulation disorders and sometimes disseminated intravascular coagulation. ${ }^{6} 1617$ These coagulation abnormalities could be explained by an extensive bidirectional interaction between sepsis and coagulation. ${ }^{6918} 19$ Moreover, proinflammatory cytokines and chemokines are the main mediators in this interaction between sepsis and coagulation. ${ }^{18}$

As previously shown, pneumonia as compared with other types of infections was associated with higher mortality. ${ }^{20-22}$ Even though bacteraemia was not associated with worst outcome, it was more common among patients that developed septic shock. Gram-negative pathogens predominated in our cohort, since urinary tract infections were the most common type of infection for which microbiological documentation is higher as comparison to other types of infections and especially pneumonia.

In the present study, a high percentage of patients (84.3\%) carried at least one thrombophilic mutations, which is in accordance with previous studies conducted in general population, as well as in patients with sepsis. ${ }^{23-28}$ Moreover, percentages of individual mutations are comparable to that reported from studies deriving from Europe. Even though most of patients included carried thrombophilic mutations, mortality was influenced by neither individual mutations nor accumulation of such mutations.

Fibrinogen's role in the survival from infection and especially sepsis has been previously established, with higher fibrinogen levels being associated with higher survival. ${ }^{29}$ An association between higher plasma fibrinogen levels and $-455 \mathrm{G} / \mathrm{A}$ polymorphism in the promoter region of the fibrinogen-beta gene has been shown by previous studies. ${ }^{30}$ Even though we found that lower levels of fibrinogen led to higher mortality, the presence of heterozygous $(n=34$ patients) or homozygous $(n=6)-455$ G/A polymorphism was not associated with better outcome.

PAI-1 is a crucial inhibitor of fibrinolysis by inhibiting plasminogen activator, so high circulating levels lead to disseminated intravascular coagulation and organ dysfunction and are associated with worst outcome in infected patients and development of septic shock. ${ }^{31}$ The most common studied polymorphism was a deletion/insertion $(4 \mathrm{G} / 5 \mathrm{G})$ one in the promoter region of aforementioned gene. The $4 \mathrm{G}$ allele (four guanine bases) has been consistently associated with higher levels of PAI-1, thus leading to higher mortality among septic patients. ${ }^{32} 33$ To the best of our knowledge, this is the first study to report that $5 \mathrm{G} / 5 \mathrm{G}$ genotype, as compared with both $4 \mathrm{G} / 4 \mathrm{G}$ and $4 \mathrm{G} / 5 \mathrm{G}$, was associated with a higher risk for septic shock development, even though no association with mortality was found. A possible explanation for our results may be that production of PAI- 1 is influenced apart from genetic factors by many other determinants including metabolic factors, lifestyle, renin-angiotensin system and other inflammatory mediators. $^{3234}$

From the remaining studied mutations (factor V G1691A (Leiden), factor V H1299R (R2), prothrombin G20210A, MTHFR C677T, MTHFR A1298C and factor XIII V34L), 
fVL mutation was the most thoroughly investigated in experimental murine models and clinical sepsis studies with controversial results. In a Danish population-based study, $\mathrm{fVL}$ mutation was associated with an increased risk of a 28-day mortality among septic patients, ${ }^{35}$ while Kerlin et $a l^{28}$ showed a survival advantage among heterozygous fVL septic patients as compared with non-carriers. Nevertheless, a recent meta-analysis showed no association between fVL mutation and mortality risk. ${ }^{12}$ In the present study, fVL mutation had no influence on mortality, but only four patients (5.6\%) were heterozygotes.

The study had some limitations. The development of sepsis and organ dysfunction after an infection has to be considered as an individualised process. The sample size in our study was relatively small for a condition that varies substantially in its clinical spectrum and severity. Even though most of the patients included had at least one thrombophilic mutation, the effect of some rare polymorphisms could not be properly evaluated. Second, no measurement of PAI-1 circulating levels was conducted in order to evaluate if the effect of $5 \mathrm{G} / 5 \mathrm{G}$ genotype on septic shock development was a random association or was associated with higher circulating PAI-1 levels.

Although coagulopathy disorders, such as low fibrinogen levels, play an important role in sepsis-related mortality, the role of individual or combination of thrombophilic mutations remains unclear. PAI-1 5G/5G genotype, as compared with both $4 \mathrm{G} / 4 \mathrm{G}$ and $4 \mathrm{G} / 5 \mathrm{G}$, was associated with higher risk for septic shock development, while none of the studied polymorphisms influenced mortality. Consequently, future studies with large number of participants are needed in order to clarify the impact of haemostatic gene polymorphisms on mortality among the patients with sepsis or septic shock.

Contributors MM and MK conceived the idea and experimental design. AG and MP-O collected the patients' data. AG collected the blood samples. AG and MK conducted the molecular experiments. MM supervised the project. MP-O and AG performed the analysis and interpreted the results. AG and MP-O wrote the manuscript. All authors contributed to manuscript revision, read and approved the submitted version.

Funding The authors have not declared a specific grant for this research from any funding agency in the public, commercial or not-for-profit sectors.

Competing interests None declared.

Patient consent for publication Not required.

Ethics approval The study was approved by the Hospital Ethics Committee (no. 571).

Provenance and peer review Not commissioned; externally peer reviewed.

\section{ORCID ID}

Markos Marangos http://orcid.org/0000-0001-5030-2398

\section{REFERENCES}

1 Singer M, Deutschman CS, Seymour CW, et al. The Third International Consensus Definitions for Sepsis and Septic Shock (Sepsis-3). JAMA 2016;315:801-10.

2 Horan TC, Andrus M, Dudeck MA. CDC/NHSN surveillance definition of health care-associated infection and criteria for specific types of infections in the acute care setting. Am J Infect Control 2008;36:309-32.

3 Schouten M, Wiersinga WJ, Levi M, et al. Inflammation, endothelium, and coagulation in sepsis. J Leukoc Biol 2008;83:536-45.

4 Munford R, Suffredini A. Sepsis, severe sepsis, and septic Shock. In: Mandell G, Bennett J, Dolin R, eds. Mandell, Douglas, and Bennett's Principles and Practice of Infectious Diseases: Elsevier, 2010:987-1010.
5 Semeraro N, Ammollo CT, Semeraro F, et al. Sepsis, thrombosis and organ dysfunction. Thromb Res 2012;129:290-5.

6 Levi M, Schultz M, van der Poll T. Sepsis and thrombosis. Semin Thromb Hemost 2013;39:559-66.

7 Aird WC. Vascular bed-specific hemostasis: role of endothelium in sepsis pathogenesis. Crit Care Med 2001;29:S28-34. discussion S34-5.

8 Texereau J, Pene F, Chiche JD, et al. Importance of hemostatic gene polymorphisms for susceptibility to and outcome of severe sepsis. Crit Care Med 2004;32:5313-9.

9 Levi M, van der Poll T, Büller HR. Bidirectional relation between inflammation and coagulation. Circulation 2004;109:2698-704.

10 Kaplan D, Casper TC, Elliott CG, et al. VTE Incidence and Risk Factors in Patients With Severe Sepsis and Septic Shock. Chest 2015;148:1224-30.

11 Rhodes A, Evans LE, Alhazzani W, et al. Surviving Sepsis Campaign: International Guidelines for Management of Sepsis and Septic Shock: 2016. Intensive Care Med 2017;43:304-77.

12 Zhang J, He Y, Song W, et al. Lack of association between factor V Leiden and sepsis: a meta-analysis. Clin Appl Thromb Hemost 2015;21:204-10.

13 Kondaveeti S, Hibberd ML, Booy R, et al. Effect of the Factor V Leiden mutation on the severity of meningococcal disease. Pediatr Infect Dis J 1999;18:893-6.

14 Binder A, Endler G, Müller M, et al. 4G4G genotype of the plasminogen activator inhibitor-1 promoter polymorphism associates with disseminated intravascular coagulation in children with systemic meningococcemia. J Thromb Haemost 2007;5:2049-54.

15 Levy MM, Fink MP, Marshall JC, et al. SCCM/ESICM/ACCP/ATS/SIS International Sepsis Definitions Conference. Crit Care Med 2001;2003:1250-6.

16 Levi M. The coagulant response in sepsis. Clin Chest Med 2008;29:627-42.

17 Levi M, van der Poll T, Schultz M. New insights into pathways that determine the link between infection and thrombosis. Neth J Med 2012;70:114-20.

18 Levi M, van der Poll T. Two-way interactions between inflammation and coagulation. Trends Cardiovasc Med 2005;15:254-9.

19 Levi M, van der Poll T. Coagulation and sepsis. Thromb Res 2017;149:38-44.

20 Falagas ME, Korbila IP, Kapaskelis A, et al. Trends of mortality due to septicemia in Greece: an 8-year analysis. PLoS One 2013;8:e67621.

21 Papadimitriou-Olivgeris M, Aretha D, Zotou A, et al. The Role of Obesity in Sepsis Outcome among Critically III Patients: A Retrospective Cohort Analysis. Biomed Res Int 2016;2016:1-9.

22 Mansur A, Klee Y, Popov AF, et al. Primary bacteraemia is associated with a higher mortality risk compared with pulmonary and intra-abdominal infections in patients with sepsis: a prospective observational cohort study. BMJ Open 2015;5:e006616.

23 Karakantza M, Androutsopoulos G, Mougiou A, et al. Inheritance and perinatal consequences of inherited thrombophilia in Greece. Int J Gynaecol Obstet 2008:100:124-9.

24 Franco RF, Reitsma PH. Genetic risk factors of venous thrombosis. Hum Genet 2001:109:369-84.

25 Buchanan GS, Rodgers GM, Ware Branch D. The inherited thrombophilias: genetics, epidemiology, and laboratory evaluation. Best Pract Res Clin Obstet Gynaecol 2003;17:397-411.

26 Middeldorp S, Levi M. Thrombophilia: an update. Semin Thromb Hemost 2007;33:563-72.

27 Tsantes AE, Tsangaris I, Bonovas S, et al. The effect of four hemostatic gene polymorphisms on the outcome of septic critically ill patients. Blood Coagul Fibrinolysis 2010;21:175-81.

28 Kerlin BA, Yan SB, Isermann BH, et al. Survival advantage associated with heterozygous factor $\mathrm{V}$ Leiden mutation in patients with severe sepsis and in mouse endotoxemia. Blood 2003;102:3085-92.

29 Kaspereit F, Doerr B, Dickneite $G$. The effect of fibrinogen concentrate administration on coagulation abnormalities in a rat sepsis model. Blood Coagul Fibrinolysis 2004;15:39-43.

30 Manocha S, Russell JA, Sutherland AM, et al. Fibrinogen-beta gene haplotype is associated with mortality in sepsis. J Infect 2007:54:572-7.

31 Tipoe TL, Wu WKK, Chung L, et al. Plasminogen Activator Inhibitor 1 for Predicting Sepsis Severity and Mortality Outcomes: A Systematic Review and Meta-Analysis. Front Immunol 2018;9:1218.

32 Hermans PW, Hazelzet JA. Plasminogen activator inhibitor type 1 gene polymorphism and sepsis. Clin Infect Dis 2005;41(Suppl 7):S453-8.

33 Li L, Nie W, Zhou H, et al. Association between plasminogen activator inhibitor-1 - 675 4G/5G polymorphism and sepsis: a meta-analysis. PLoS One 2013:8:e54883

34 Horrevoets AJ. Plasminogen activator inhibitor 1 (PAI-1): in vitro activities and clinical relevance. Br J Haematol 2004;125:12-23.

35 Benfield TL, Dahl M, Nordestgaard BG, et al. Influence of the factor V Leiden mutation on infectious disease susceptibility and outcome: a population-based study. J Infect Dis 2005;192:1851-7. 